\title{
Evaluation of Health Risks Related to the Consumption of Fish from the Guéssabo River
}

\author{
Paul Attienn,2,3*, Evelyne Toe ${ }^{4}$, Kra Athanase Kouassi1,3, Arthur Constant Zébré1, \\ Mamayé Neolly Gomé1, Haziz Sina², Nanouman Marina Christelle Assohoun-Djeni1, \\ Arsene Konan', Ibourehema Coulibaly¹, Baba-Moussa Lamine², Adjehi Dadie ${ }^{3}$
}

\author{
${ }^{1}$ Department of Biochemistry and Microbiology, Laboratory of Agrovalorisation, Jean Lorougnon Guede University, Daloa, \\ Côte d'Ivoire \\ ${ }^{2}$ Laboratory of Biology and Molecular Typing in Microbiology, Faculty of Science and Technology, University of Abomey-Calavi, \\ Cotonou, Benin \\ ${ }^{3}$ Department of Food Science and Technology, Laboratory of Food Biotechnology and Microbiology, Nangui Abrogoua \\ University, Abidjan, Côte d'Ivoire \\ ${ }^{4}$ Training and Research Unit of Biological Sciences, Department of Biochemistry-Genetic, University of Peleforo Gon Coulibaly, \\ Korhogo, Côte d'Ivoire \\ Email: *attienyaopaulusa@gmail.com
}

How to cite this paper: Attien, P., Toe, E., Kouassi, K.A., Zébré, A.C., Gomé, M.N., Sina, H., Assohoun-Djeni, N.M.C., Konan, A., Coulibaly, I., Lamine, B.-M. and Dadie, A. (2022) Evaluation of Health Risks Related to the Consumption of Fish from the Guéssabo River. Food and Nutrition Sciences, 13, 55-64.

https://doi.org/10.4236/fns.2022.131006

Received: November 18, 2021

Accepted: January 23, 2022

Published: January 26, 2022

Copyright $\odot 2022$ by author(s) and Scientific Research Publishing Inc. This work is licensed under the Creative Commons Attribution International License (CC BY 4.0).

http://creativecommons.org/licenses/by/4.0/

(c) (i) Open Access

\begin{abstract}
Fish is rich in essential nutrients but can remain a potential source of food poisoning. A study was, therefore, carried out with the general objective of highlighting the probable biological and chemical dangers associated with the consumption of fish and freshwater fruits from the Guéssabo river. The present study was conducted on 50 carp fish, 50 mackerel fish, 50 frogs and $50 \mathrm{~mol}-$ lusks caught in the Guéssabo River. Microorganisms were enumerated by conventional tests and heavy metals were investigated by Inductively Coupled Plasma Optical Emission Spectrometry. The enumeration showed high levels of thermotolerant Coliforms $\left(2.5 \times 10^{4}\right)$, Enterobacteriaceae $\left(3.4 \times 10^{4}\right), S$. aureus $\left(2.3 \times 10^{3}\right)$ and Yeast/Molds $\left(2.1 \times 10^{4}\right)$, in all samples the standards were not in conformity with the required standards. High levels of $\mathrm{Al}$ (7230 $\mu \mathrm{g} / \mathrm{kg})$ and $\mathrm{Cd}(21.57 \mu \mathrm{g} / \mathrm{kg})$ were observed in carp fish and these values are above the standard. In conclusion, the fish caught in the Guéssabo River could be a health risk factor for the consumer.
\end{abstract}

\section{Keywords}

Fish, Microorganisms, Heavy Metals, Sanitary Quality, Guéssabo River of Côte D'Ivoire

\section{Introduction}

Fish is recognized as one of the richest food for accessing a well-balanced diet. 
Nutrients such as high-quality protein, vitamins, polyunsaturated fatty acids, and omega-3s, strengthen the body as well as reduce the risk of coronary heart disease and neurological disease [1] [2] [3]. Thus, for their good health, it is recommended the consumption of fish should be at least per week [1]. However, the consumption of fish and seafood can potentially harmful because of their biochemical, microbiological, and physicochemical quality due to their sources of origins [4]. Indeed, fish normally accumulates heavy metals from food, water, and sediments [5] [6] [7] and this is a good indicator of heavy metals contamination in water [8]. While microbiological contamination is responsible for gastroenteritis, this is not the case for heavy metals. Several unfavorable effects of heavy metals on human health have been known for a long time [4]. This includes serious threats like renal failure, liver damage, cardiovascular diseases, and even death [9] [10]. Thus, many local and international monitoring programs have been established to assess the quality of fish for human consumption and to monitor the health of the aquatic ecosystem [11].

In Côte d'Ivoire, fish is the primary source of animal protein for the Ivorian consumer. National fish consumption is estimated to vary between 250,000 and 300,000 tons/year for an average local production of 80,000 tons [12]. Given its relatively low price compared to that of meat, fish is accessible to the most modest households [13]. Local production comes from high seas fishing but also from many rivers and streams that cover the country. In the region of Haut Sassandra, the halieutic products sold on the different markets come from the Guessabo River [14]. The study of the sanitary quality of these products is, therefore, of paramount importance given the strong demand for freshwater fish and fruits by the populations of Upper Sassandra. It seemed appropriate to us to study the quality of these products with a view to answering the questions of health safety related to the consumption of these products. A study was, therefore, carried out and aimed at highlighting the probable biological and chemical dangers associated with the consumption of fish and freshwater fruits from the Guéssabo River. It focused on the evaluation of microbiological quality by researching germs such as enterobacteria, fungal flora and the heavy metals toxicity of fish and freshwater fruits from the Guéssabo River.

\section{Material and Methods}

\subsection{Study Area}

This study was carried out in the town of Guéssabo. This city is located in central western Côte d'Ivoire. She is from the department of Zoukougbeu, in the Haut-Sassandra region. Its geographic coordinates are latitude $6^{\circ} 44^{\prime} 12^{\prime \prime}$ north latitude and $6^{\circ} 57^{\prime} 17.5^{\prime \prime}$ west longitude. The town of Guéssabo has a river (Figure 1) which is a tributary of the Sassandra River, and which bears the same name as the town. It has a landing stage where the populations of the department and the region come to stock up on fishery products [14]. 

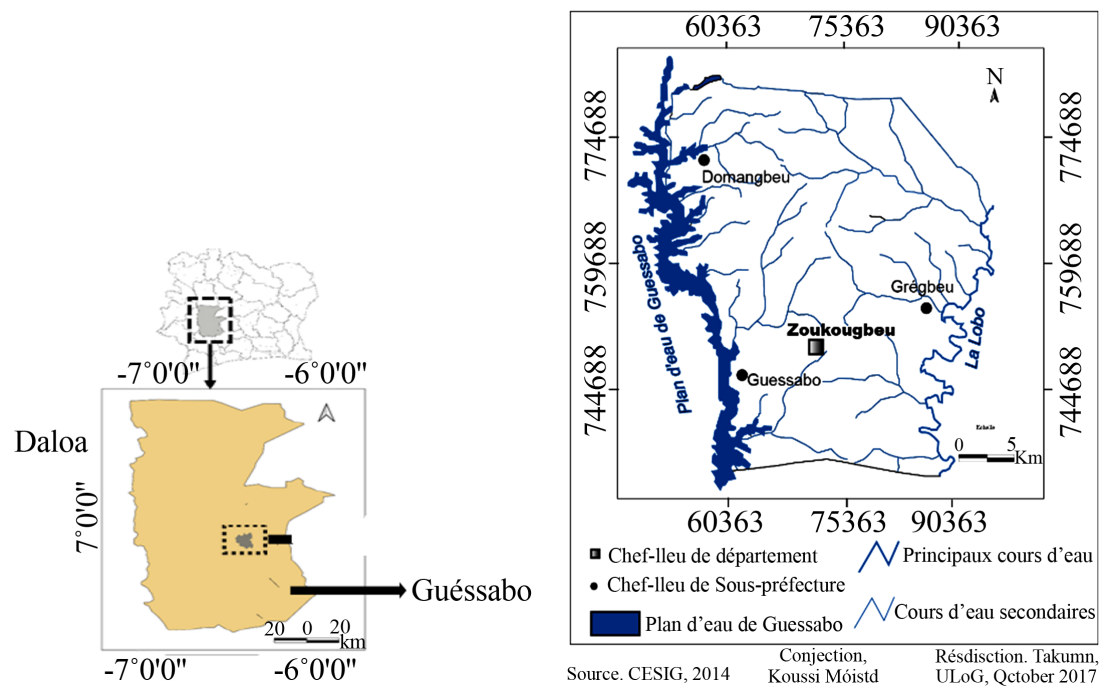

Figure 1. Map showing Guéssabo River.

\subsection{Data Collection}

The calculation of the size of the fish and seafood samples was analyzed according to the formula of Dagnelie et al. [15]:

$$
n=\frac{U_{1-\frac{a}{2}}^{2} \times p(1-p)}{d^{2}}
$$

where: $n$ : size of the surveyed population; $p$ : prevalence of consumption of freshwater fish and fruit; $d$ : margin of error. The various samples were taken during the rainy season in July. The fish (Cyprinus carpio and Arius africanus), frog (Rana brama) and mollusca (Pomacea canaliculat) samples were purchased on board (Figure 2). The samples consist of 50 frogs 50 carp fish, 50 jaws and 50 mollusks. They were collected randomly and transported in coolers with ice accumulators to the Microbiology Laboratory of the University of Jean Lorougnon Guédé in ice accumulator's container for microbiological analysis and research for heavy metals.

\subsection{Microbiological Analysis}

\section{Bacteria isolation and identification}

The microbiological analysis consisted in looking for the following germs: Total and thermotolerant coliforms (NF ISO 4831), Staphylococcus aureus (NF EN ISO 6888-1), Salmonella $s p$ (NF V 08-052), yeasts and molds (ISO 7954) [16]. The culture media below in summer use according to the manufacturer's recommendations is in Table 1.

\subsection{Sample Analysis}

\section{Bacteria isolation and identification}

Twenty-five (25) grams of each sample are weighed aseptically and then placed in a sterile Erlenmeyer flask. A volume of $225 \mathrm{ml}$ of Buffered Peptone 


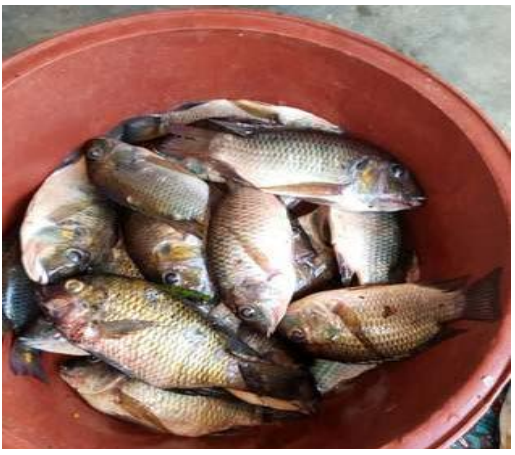

(a)

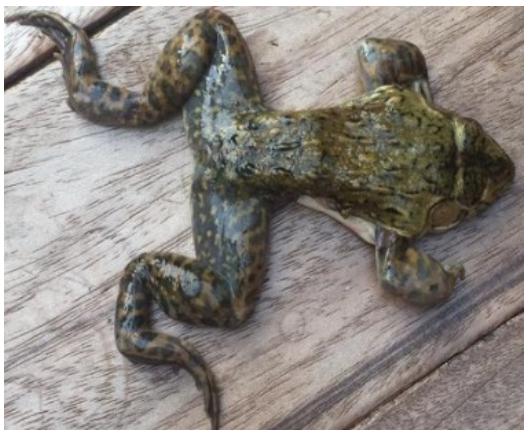

(c)

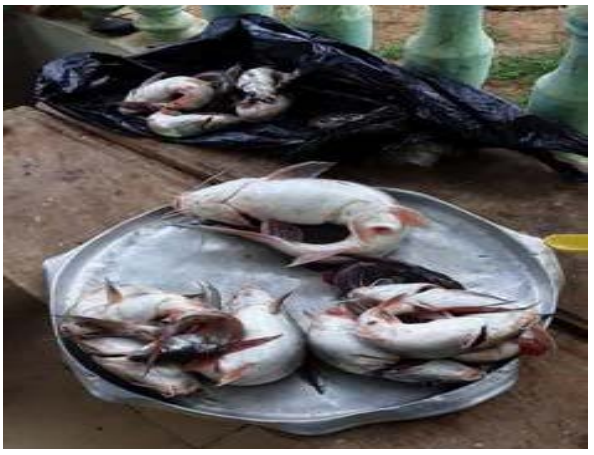

(b)

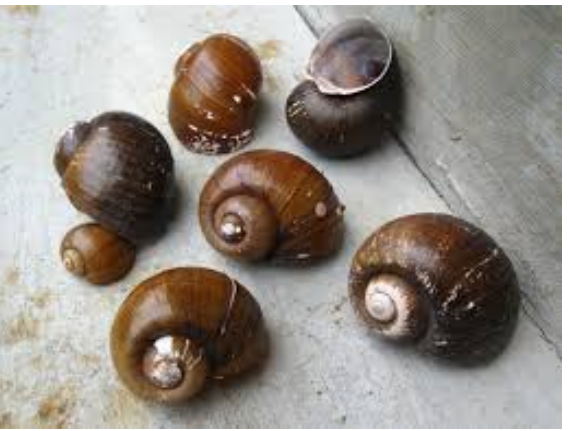

(d)

Figure 2. Pictures of the targeted freshwater fish and fruit. (a) Cyprinus carpio; (b) Arius africanus; (c) Rana brama; (d) Pomacea canaliculat.

Table 1. Media used.

\begin{tabular}{cc}
\hline Target microorganisms & Culture media used \\
\hline Thermotolerant coliforms & VRBG agar (diagnostici-liofilchem) \\
Total coliforms & VRBL agar (diagnostici-liofilchem) \\
Fungal flora & Sabouraud with chloramphenicol (alpha biosciences) \\
Staphylococcus aureus & Baird parker (Eur pharm) \\
Salmonella & Hektoen, (biosciences) rappaport de vassiliadis (bio rad) \\
\hline
\end{tabular}

Water is added thereto. The mixture was homogenized for 2 min to obtain the stock suspension corresponding to the $10^{-1}$ dilution. This solution is left to stand for $30 \mathrm{~min}$, to dissolve and allow revivification of the microorganisms at room temperature (about $25^{\circ} \mathrm{C}$ ). From this suspension, a series of decimal dilutions is then carried out. Two types of inoculation were carried out during this manipulation. These are mass seeding which concerned Sabouraud media with chloramphenicol, VRBL, and VRBG, and surface seeding by spreading which considered the media, Baird Parker, surface seeding by streak which concerns the Hecktoen medium. The isolation and identification of salmonella was carried out according to Adane et al. [17] protocol.

\section{Colony enumeration}

Colony forming units per milliliter of sample (CFU/g) were calculated accord- 
ing to standard NF/ISO 7218: 2007 using the following formula:

$$
N=\frac{\sum C}{V \times\left(n_{1}+0.1 \times n_{2}\right) \times d}
$$

$\Sigma C$ : sum of characteristic colonies counted on all retained Petri dishes; $n_{1}$ : number of Petri dishes retained at the first dilution; $n_{2}$ : number of Petri dishes retained at the second dilution; $d$ : dilution rate corresponding to the first dilution; $V$ : inoculated volume $(\mathrm{mL}) ; N$ : number of microorganisms (CFU/g).

\section{Quality assessment criterion}

This evaluation was carried out using as supports, the standard analysis techniques reported by Joffin and Joffin [18] according to the two-class plan with reference to the microbiological criteria for fresh animal products specified by the French Legislative and Regulatory Guide No. 8155 (GLF 2000). The tolerance thresholds are $\mathrm{M}=10{ }^{3} \mathrm{CFU} / \mathrm{g}$ or $\mathrm{ml}$ for the total flora; at $10 \mathrm{CFU} / \mathrm{g}$ or $\mathrm{ml}$ for fecal coliforms and the absence in $25 \mathrm{~g}$ of product analyzed for salmonella.

\subsection{Trace Metals Analysis}

The metal (Al, As, Cd, Co, Cr, Cu, Fe, Hg, Mg, Ni, Mn, Pb, Sb, Zn, B and Ba) content in the sample were determined by the method of Inductively coupled plasma optical emission spectroscopy (ICP/OES) according to the protocol of Bozorgzadeh et al. [19]. The fish samples were washed thoroughly by water and wrapped into separate polyethylene bags and were immediately frozen and stored at $-20^{\circ} \mathrm{C}$ until examination. Before analysis the fish specimens were thawed, and a stainless-steel knife was used to cut the tissues. Samples of fish fillets were quickly removed and washed with Milli-Q water. The fish fillets $(0.5 \mathrm{~g})$ were thoroughly homogenized in a food blender with stainless steel cutters. The prepared sample was added to $25 \mathrm{~mL}$ of $3: 2$ ratios of $\mathrm{HNO}_{3}: \mathrm{H}_{2} \mathrm{O}_{2}(32 \%)$ in a screw cap polypropylene sample tube. The cap was tightened, and the tube was placed in a water bath at $85^{\circ} \mathrm{C}$ for $2 \mathrm{~h}$. After digestion, the liquid portion was separated, vacuum dried to $1 \mathrm{~mL}$ and used for further analysis.

\subsection{Statistical Analysis}

The results were statistically analyzed of variance method (ANOVA) using the STATISTICA 7.1 software (Statsoft, France). The comparison of means is carried out by the test of the smallest significant difference the test of Tukey. The differences are significant when $p<0.05$. When the probability is greater than 0.05 ( $p>0.05)$ the statistical differences are not significant. In the event of a significant difference $(\mathrm{p}<0.05)$ between the means, Tukey's test was performed to determine the different classes of homogeneity.

\section{Results}

\subsection{Results of the Microbiological Analysis of Samples of Fresh Fish (Carp and Jawbones), Mollusks, Frogs}

Table 2 shows the results of the analyzes of our different samples from the 
Table 2. Results of the microbiological analyzes.

\begin{tabular}{ccccc}
\hline \multirow{2}{*}{ Sample types } & $\begin{array}{c}\text { Fresh fish } \\
\text { (Carp and jawbones) }\end{array}$ & Mollusks & Frogs \\
\hline & & $3.99 \times 10^{3}$ & & $3.49 \times 10^{4}$ \\
& Total coliforms & \pm & 0 & \pm \\
& & 0.62 & & 1.71 \\
& & $4.16 \times 10^{3}$ & & $2.57 .10^{4}$ \\
Thermotolerant & coliforms & 5.71 & 0 & \pm \\
(in CFU/g) & & $5.55 \times 10^{2}$ & $5.55 \times 10^{2}$ & $2.11 \times 10^{4}$ \\
& & \pm & \pm & \pm \\
& Fungal flora & $0.17^{\mathrm{b}}$ & $0.17^{\mathrm{c}}$ & 0.74 \\
& & $2.24 \times 10^{3}$ & $9.16 \times 10^{2}$ & $2.36 \times 10^{3}$ \\
& & \pm & \pm & \pm \\
& S. aureus & 0.03 & 0.16 & 0.56 \\
& & + & - & +
\end{tabular}

+: presence of Salmonella $s p$; -: absence of Salmonella $s p$; Values assigned the same letter are statistically identical, at the $5 \%$ threshold.

Guessabo River. These results we notice that the mollusks are not contaminated by total and thermotolerant coliforms. They are only contaminated by the fungal flora with a load of $5.55 \times 10^{2} \pm 0.17 \mathrm{CFU} / \mathrm{g}$ and by $S$. aureus with a microbial load of $9.16 \times 10^{2} \pm 0.1 \mathrm{CFU} / \mathrm{g}$. Fresh fish have the lowest microbial load concerning total coliforms $\left(3.99 \times 10^{3} \pm 0.62 \mathrm{CFU} / \mathrm{g}\right)$ and thermotolerant coliforms $\left(4.16 \times 10^{3} \pm 5.71 \mathrm{CFU} / \mathrm{g}\right)$. As for Salmonella contamination, it is present in samples of frogs and fresh fish.

\subsection{Contamination of Fish and Seafood by Heavy Metals}

The heavy metal content of samples of fresh fish, frogs and Mollusca is presented in Table 3. The concentration of heavy metals: $\mathrm{As}, \mathrm{Co}, \mathrm{Cr}, \mathrm{Cu}, \mathrm{Ni}, \mathrm{Sb}, \mathrm{Cu}, \mathrm{Hg}$, is below the detection limit $(5 \mu \mathrm{g} / \mathrm{g})$ in all samples. Only fresh fish contain aluminum with a content of $7230 \mu \mathrm{g} / \mathrm{kg}$. Cd and $\mathrm{Mn}$ are present in the different samples. The content of these two metals is high in fresh fish with levels of $21.57 \mu \mathrm{g} / \mathrm{kg}$ and $95.4 \mu \mathrm{g} / \mathrm{kg}$ respectively for $\mathrm{Cd}$ and $\mathrm{Mn}$.

\section{Discussion}

This study helped to know the sanitary quality of fish and seafood caught in the Guessabo River. It was reported that freshwater fish and fruits are excellent sources of protein and other nutrients (minerals and vitamins) essential for human health [2] [3]. However, human activities and pollution induce several damages such as environment contaminations. This can make foods be contaminated by pathogenic microorganisms coming from human, animal, water or land-based present in fresh or salt water [20]. Thus, the analysis of the microbiological quality of the different samples in our study showed that they are contaminated by enterobacteria, 
Table 3. Heavy metal content of analyzed samples of fresh fish, frogs and Mollusca.

\begin{tabular}{|c|c|c|c|c|}
\hline \multirow{2}{*}{$\begin{array}{l}\text { Heavy } \\
\text { metals }\end{array}$} & Frogs & Fresh fish (carp and jawbones) & Mollusca & \multirow{2}{*}{$\begin{array}{l}\text { Maximum } \\
\text { permitted }\end{array}$} \\
\hline & \multicolumn{3}{|c|}{$\mu \mathrm{g} / \mathrm{kg}$} & \\
\hline $\mathrm{Al}$ & $<5$ & 7230 & $<5$ & - \\
\hline As & $<5$ & $<5$ & $<5$ & 1 \\
\hline $\mathrm{Cd}$ & 12.77 & 21.57 & 3.439 & 2 \\
\hline Co & $<5$ & $<5$ & $<5$ & - \\
\hline $\mathrm{Cr}$ & $<5$ & $<5$ & $<5$ & 1 \\
\hline $\mathrm{Cu}$ & $<5$ & $<5$ & $<5$ & 500 \\
\hline $\mathrm{Fe}$ & $<50$ & $<50$ & $<50$ & - \\
\hline $\mathrm{Hg}$ & $<0.5$ & $<0.5$ & $<0.5$ & 0.5 \\
\hline $\mathrm{Mn}$ & 8.7 & 95.4 & 654 & - \\
\hline $\mathrm{Ni}$ & $<5$ & $<5$ & $<5$ & 30 \\
\hline $\mathrm{Pb}$ & $<5$ & $<5$ & $<5$ & 6 \\
\hline $\mathrm{Sb}$ & $<5$ & $<5$ & $<5$ & 1 \\
\hline $\mathrm{Zn}$ & 7868 & 4562 & 4028 & 500 \\
\hline B & 3104 & 1872 & 246.4 & - \\
\hline $\mathrm{Ba}$ & 1768 & 706.6 & 796.9 & - \\
\hline
\end{tabular}

fungal flora, $S$. aureus and Salmonella. The microbial flora of frog, fish and Mollusca may be the reflect of the microbiological quality of the water in which they were collect [21]. Thus, we can say that the water from which the samples were collected is not safe of microbial contamination. It was observed that the microbial load of these bacteria varies from one type of sample to another. This load is higher than the recommended standard: Enterobacteria's $\leq 10 \mathrm{CFU} / \mathrm{g}$, fungal flora $\leq 10^{5} \mathrm{CFU} / \mathrm{g}$ and Salmonella (absent). Enterobacteriaceae represent the highest bacterial load. This observation is identical to the work of Kolda et al. [22]. However, fresh poisons and frogs are the most contaminated. The presence of Enterobacteriaceae indicates fecal contamination and their main reservoir is the human digestive tract. Indeed, certain rivers are the place of dumping of all types of human waste [22] [23]. The contamination is therefore explained by the fact that the Microbiota of water and fish are interconnected in the aquatic environment, with the possibility of bacteria colonizing the host's skin, gills or intestinal tract [24]. In the second part of this study, we evaluated the level of chemical contamination by heavy metals. The main heavy metals that have a strong negative impact on human health are lead, cadmium, mercury and arsenic [25]. The analysis of our different samples showed that none of the seafood products exceeded the EU maximum level for mercury and the cadmium in fish of 0.50 
$\mathrm{mg} / \mathrm{kg}$. Our results for mercury and cadmium agree with those of Naess et al. [26] who found values below the limit recommended in the chemical analysis of seafood from 2015 to 2018 in Norway. On the other hand, we observed a high concentration of aluminum content in the fresh poisons $(7230 \mu \mathrm{g} / \mathrm{Kg})$. This effect is the fact that the toxicity of aluminum with respect to aquatic organisms depends on the physicochemical conditions of the environment. Studies on this subject have shown that the inorganic forms of this metal are particularly toxic to fish depending on the $\mathrm{pH}$ [27]. Aluminum is the $3^{\text {rd }}$ mineral element most common in the earth's crust after silica. It is therefore omnipresent in the environment. It is never found in nature in metallic form, but always combined with other elements, notably with oxygen [28]. Acid precipitation which passes through soils can induce the mobilization of certain elements ( $\mathrm{Al}, \mathrm{Mn}, \mathrm{Fe}, \mathrm{Zn}$, etc.), sometimes in quantities toxic to aquatic ecosystems [29]. This high load of aluminum rate could therefore be explained by the fact the southwest zone where the Guéssabo river is located is a rainy zone where precipitations very often reach 1200 to 1400 mm per year [30].

\section{Conclusion}

At the end of this study, we can retain that the fish and seafood from the Guéssabo River are made up of carp, mollusks and frogs. The consumption of these products presents some risks for human health. In fact, the microbiological analysis of the different samples showed contamination by enterobacteria including Salmonella. This bacterium is responsible for typhoid fever. In addition, some trace metals (mercury, cadmium, and arsenic) were recorded below the thresholds of dangerousness for human health. These are mercury, cadmium, and arsenic. Unfortunately, the level of lead remains very high in fresh fish.

\section{Conflicts of Interest}

The authors declare no conflicts of interest regarding the publication of this paper.

\section{References}

[1] Kris-Etherton, P.M., Harris, W.S. and Appel, L.J. (2002) Fish Consumption, Fish Oil, Omega-3 Fatty Acids, and Cardiovascular Disease. Circulation, 106, 2747-2757. https://doi.org/10.1161/01.CIR.0000038493.65177.94

[2] Tilami, S.K. and Sampels, S. (2018) Nutritional Value of Fish: Lipids, Proteins, Vitamins, and Minerals. Reviews in Fisheries Science \& Aquaculture, 26, 243-253. https://doi.org/10.1080/23308249.2017.1399104

[3] Aakre, I., Næss, S., Kjellevold, M., Markhus, M.W., Alvheim, A.R., Dalane, J., Kielland, E. and Dahl, L. (2019) New Data on Nutrient Composition in Large Selection of Commercially Available Seafood Products and Its Impact on Micronutrient Intake. Journal of Food Science, 63, Article No. 3573. https://doi.org/10.29219/fnr.v63.3573

[4] Castro-Gonzalez, M.I. and Mendez-Armenta, M. (2008) Heavy Metals: Implications Associated to Fish Consumption. Environmental Toxicology and Pharmacology, 26, 
263-271. https://doi.org/10.1016/j.etap.2008.06.001

[5] Yilmaz, F., Ozdemir, N., Demirak, A. and Tuna, A.L. (2007) Heavy Metal Levels in Two Fish Species Leuciscus cephalus and Lepomis gibbosus. Food Chemistry, 100, 830-835. https://doi.org/10.1016/j.foodchem.2005.09.020

[6] Zhao, Z., Feng, C., Quan, W., Chen, X., Niu, J. and Shen, Z. (2012) Role of Living Environments in the Accumulation Characteristics of Heavy Metals in Fishes and Crabs in the Yangtze River Estuary, China. Marine Pollution Bulletin, 64, 1163-1171. https://doi.org/10.1016/j.marpolbul.2012.03.023

[7] Bawuro, A.A., Voegborlo, R.B. and Adimado, A.A. (2018) Bioaccumulation of Heavy Metals in Some Tissues of Fish in Lake Geriyo, Adamawa State, Nigeria. Journal of Environmental and Public Health, 2018, Article ID: 1854892. https://doi.org/10.1155/2018/1854892

[8] Voegborlo, R.B., Atta, A. and Agorku, E.S. (2012) Total Mercury Distribution in Different Tissues of Six Species of Freshwater Fish from the Kpong Hydroelectric Reservoir in Ghana. Environmental Modeling \& Assessment, 184, 3259-3265. https://doi.org/10.1007/s10661-011-2186-4

[9] Al-Busaidi, M., Yesudhason, P., Al-Mughairi, S., Al-Rahbi, W.A.K., Al-Harthy, K.S., Al-Mazrooei, N.A. and Al-Habsi, S.H. (2011) Toxic Metals in Commercial Marine Fish in Oman with Reference to National and International Standards. Chemosphere, 85, 67-73. https://doi.org/10.1016/j.chemosphere.2011.05.057

[10] Rahman, M.S., Molla, A.H., Saha, N. and Rahman A. (2012) Study on Heavy Metals Levels and Its Risk Assessment in Some Edible Fishes from Bangshi River, Savar, Dhaka, Bangladesh. Food Chemistry, 134, 1847-1854.

https://doi.org/10.1016/j.foodchem.2012.03.099

[11] Meche, A., Martins, M.C, Lofrano, B.E.S.N., Hardaway. C.J., Merchant, M. and Verdade, L. (2010) Determination of Heavy Metals by Inductively Coupled Plasma-Optical Emission Spectrometry in Fish from the Piracicaba River in Southern Brazil, Microchemical Journal, 94, 171-174. https://doi.org/10.1016/j.microc.2009.10.018

[12] Yao, A.H., Koumi, A.R., Atse, B.C. and Kouamelan, E.P. (2017) État des connaissances sur la pisciculture en Côte d'Ivoire. Agronomie Africaine, 29, 227-244.

[13] Food and Agriculture Organization of the United Nations (2018) The State of Fisheries and Aquaculture, Meeting the Sustainable Development Goals, 227 p. https://www.was.org/aqua18pressconference/ documents/FAO2018 TheStateOf Wo rld Fisheries And Aquaculture.pdf

[14] Rosenthal, I. (2019) Improving Rural Services for Small-Scale Fisheries Using a Technological Platform Approach. FAO Fisheries and Aquaculture Circular, (C1180), I-25, Food and Agriculture Organization of the United Nations, Rome.

[15] Dagnelie, P. (1998) Theoretical and Applied Statistics. Vol. 2, De Boeck \& Larcier, Paris, Belgium, 659 p.

[16] European Communities (2006) Commission Regulation (EC) No 1881/2006 of 19 December 2006 Setting maximum Levels for Certain Contaminants in Foodstuffs. Official Journal of the European Union, Article No L 364/5.

[17] Adane, M., Teka, B., Gismu, Y., Halefom, G. and Ademe, M. (2018) Food Hygiene and Safety Measures among Food Handlers in Street Food Shops and Food Establishments of Dessie Town, Ethiopia: A Community-Based Cross-Sectional Study. PLoS ONE, 13, Article ID: e0196919. https://doi.org/10.1371/journal.pone.0196919

[18] Joffin, C. and Joffin, J-N. (2003) Microbiologie alimentaire. Biologie et Technique, 5è édition, CRDP Aquitaine, Bordeaux, 212 p.

[19] Bozorgzadeh, E., Pasdaran, A. and Ebrahimi-Najafabadi, H. (2021) Determination 
of Toxic Heavy Metals in Fish Samples Using Dispersive Micro Solid Phase Extraction Combined with Inductively Coupled Plasma Optical Emission Spectroscopy. Food Chemistry, 346, Article ID: 128916. https://doi.org/10.1016/j.foodchem.2020.128916

[20] Hernández-Cortez, C., Palma-Martínez, I., Gonzalez-Avila, L.U., Guerrero-Mandujano, A., Solís, R.C. and Castro-Escarpulli, G. (2017) Food Poisoning Caused by Bacteria (Food Toxins). In: Malangu, N., Ed., Poisoning: From Specific Toxic Agents to Novel Rapid and Simplified Techniques for Analysis, IntechOpen, London, 33. https://doi.org/10.5772/intechopen.69953

[21] Feldhusen, F. (2000) The Role of Seafood in Bacterial Foodborne Diseases. Microbes and Infection, 2, 1651-1660. https://doi.org/10.1016/S1286-4579(00)01321-6

[22] Kolda, A., Mujakić, I., Perić, L., Smrzlić, I.V. and Kapetanović, D. (2020) Microbiological Quality Assessment of Water and Fish from Karst Rivers of the Southeast Black Sea Basin (Croatia), and Antimicrobial Susceptibility of Aeromonas Isolates. Current Microbiology, 77, 2322-2332. https://doi.org/10.1007/s00284-020-02081-5

[23] Rodríguez-Tapia, L. and Morales-Novelo, J.A. (2017) Bacterial Pollution in River Waters and Gastrointestinal Diseases. International Journal of Environmental Research and Public Health, 14, Article No. 479. https://doi.org/10.3390/ijerph14050479

[24] Verschuere, L., Rombaut, G., Sorgeloos, P. and Verstraete, W. (2000) Probiotic Bacteria as Biological Control Agents in Aquaculture. Microbiology and Molecular Biology Reviews, 64, 655-671. https://doi.org/10.1128/MMBR.64.4.655-671.2000

[25] Järup, L. (2003) Hazards of Heavy Metal Contamination. British Medical Bulletin, 68, 167-182. https://doi.org/10.1093/bmb/ldg032

[26] Næss, S., Aakre, I., Lundebye, A., Ørnsrud, R., Kjellevold, M., Wik, M. and Dahl, L. (2020) Mercury, Lead, Arsenic, and Cadmium in Norwegian Seafood Products and Consumer Exposure. Food Additives \& Contaminants Surveillance: Part B, 13, 99-106. https://doi.org/10.1080/19393210.2020.1735533

[27] Driscoll, C.T. (1980) Aqueous Spec Lat Ion of Aluminum in the Adirondack Reglon of New York State USA. Proceedings of an International Conference, Sandefjord, Norway, March 11-14 1980, 214-215.

[28] Velde, B. (2000) Clay Minerals: A Physico-Chemical Explanation of Their Occurrence. Elsevier, Amsterdam.

[29] Baker, J.P. and Schofield, C.L. (1980) Aluminum Toxicity to Fish as Related to Acid Precipitation and Adirondak Surface Water Quality [New York]. International Conference on the Ecological Impact of acid Precipitation, Sandefjord, Norway, 11-14 March 1980, 292-293.

[30] Kouamé, Y.F., Atolé, B.B.K., Seka, S., Kouassi, N.J.A., Konan, E.S., Yapo, A.B. and Gnagne, T. (2021) Physico-Chemical Characteristics of Water from Boreholes for Domestic Use in the Town of Daloa (Center-West of the Côte Ivory). International Journal of Biological and Chemical Sciences, 15, 835-845.

https://doi.org/10.4314/ijbcs.v15i2.33 